\title{
Street Tree Inventory of Campinas, Brazil: An Instrument for Urban Forestry Management and Planning
}

\author{
Ivan André Alvarez, Bruna Cristina Gallo, Edlene Aparecida Monteiro Garçon, \\ and Osvaldo Tadatomo Oshiro
}

\begin{abstract}
Campinas Metropolitan Region is the third richest city in Brazil. This study assesses the urban street trees of Campinas based on data from a survey performed using satellite images in the year 2011. All public domain trees in the street system were counted and separated into trees, shrubs, palm trees, and seedlings. The density of trees was obtained using the images census and expressed as trees per linear kilometer for the perimeter of the block. The number of trees per linear kilometer was grouped into nine classes of different densities for data validation. The final number of trees was estimated based on the validation's results. The Gini coefficient shows that the number of trees per person is very irregular in city neighborhoods (i.e., Campinas has a fairer income distribution than street trees distribution). There is a lower density of trees in the downtown area, due to the high concentration of population, and in more peripheral neighborhoods, due to the lack of design planning. The results obtained here may be used to support a new setting of local priorities for planting actions aimed at urban forestry management.

Key Words. Brazil; Campinas; Census; Density; Geoprocessing; Gini Coefficient; Remote Sensing; Street Trees; Urban Ecology; Urban Forest.
\end{abstract}

The challenge of planning urban greenspaces is to quantify them and relate them to other variables of interest to human welfare (Gong et al. 2011). Such information can be useful for sustainable action plans for the management of greenspaces, their expansion to currently empty sites, and for the preservation of animal and plant biodiversity (Alvarez 2004).

Street trees are part of the urban forest and should be evaluated in terms of their benefits: importance for the maintenance of native animal and plant biodiversity, climate comfort, and runoff interception, among others (Gong et al. 2013).

Studies on urban forests in Campinas, Brazil, have been aimed only at fragments of native forests (Santin 1999; Cielo Filho and Santin 2002; Gomes et al. 2005). Although urban forest inventories are an important aid to municipal administration planning, there is only one neighborhood street tree inventory (Aguirre 2008), and none refers to the City of Campinas as a whole. In a situation where there is a large gap of overall information about the urban trees, a quantitative survey would be the starting point for gathering reliable information.

Wood (1999) specified three types of inventory: field surveys, sample surveys, and computerizedsystem surveys. The amount of data collected defines the costs of tree inventories, which are divided in quantitative and qualitative inventories.

Tree inventory surveys are a form of supporting governmental plans. A thorough inventory of trees is extremely difficult to make in the field. For an easier inventory, it is possible to use remote-sensing and geoprocessing tools, which are faster and have a better cost-benefit ratios, creating opportunities for exploration and scientific knowledge, environmental and social analysis.

Alvarez et al. (2010) used digital data from remote sensors (videography and photography techniques) to identify the plant-cover rate of a neighborhood in Piracicaba (São Paulo State, Brazil), obtaining some indexes for the collection of biophysical information about the plants: 1 ) index of vegetation cover in urban areas (ICVAU) and 2) green index 
per inhabitant (IVH), which state the efficient use of remote sensing in urban vegetation diagnostics.

Some peculiarities about the Earth's surface may be viewed by means of the interpretation of images, thus establishing dynamic relations regarding landscape use. Applying this technique to the study of vegetation, with the purpose of managing the urban landscape, enables extracting metric information parameters about the landscape, such as fragmentation, Shannon diversity index, patterns of biophysical attributes, and vegetation polygons (number, total area, size, perimeter, shape, distance to each other), allied to the quantitative information about street trees.

The use of geoprocessing techniques enables individuals to carry out the inventory of Campinas street trees through the analysis and the processing of images. Therefore, new methods of evaluation that use satellite images and freely available tools, like the Google Street View ${ }^{\text {Tw }}$ mapping service, which can be fast and low-cost instruments for performing the quantitative inventory, are interesting advancements.

Thisstudyaimsto survey thenumber of singlestreet trees in the urban forest of Campinas, evaluate the spatial distribution of street trees in the urban perimeter, and relate this data to the population density.

\section{MATERIAL AND METHODS}

Campinas is part of the third-most important metropolitan region in Brazil, has an area of $794.43 \mathrm{~km}^{2}$ and an urban area of $386.02 \mathrm{~km}^{2}$ (Figure 1), and has a population of $1,080,113$ inhabitants (IBGE 2010a). The process of urbanization, influenced by the intense immigration over the last decades, transformed its regional space. This phenomenon has generated a new urban spatiality, resetting the areas that compose the city's territorialities. This period was marked by the growth of the cities, transforming the space; inevitably, at the same time, a 'suburbanization' of the low-income population took place, with the creation of economical-populational growth axes of distinct population characteristics. Among all the metropolitan regions in Brazil, Campinas stands out as an immigration pole in the State of São Paulo. With this trend of spatial redistribution, the region has been outlining new features and specificities of the metropolitan area. Since the 1970s, Campinas has gone through a process of evolution that explains the current demographic configuration and reveals the regional dynamics in the urban process. There is a trend toward a continuance in this immigration flow, which privileges the absorption of skilled labor (Baeninger 2005).

This study focused on urban street trees, which include sidewalks, street flowerbeds, and roundabouts, which are managed by the city council, thus excluding those located in private condominiums. Parks, squares, woods, conservation areas, and trees located on private lands were not computed in the inventory. The basic unit studied for obtaining data from the image and for validation was the block. For comparison, the data were organized by neighborhood, the basic territorial unit defined by the city hall. The urban forest was classified into three categories: tree, shrub, and palm tree.

The counting was performed by means of visual classification of a WorldView-2 orthorectified, $\mathrm{R}$ (band 1), G (band 2), B (band 3) image taken on 11 June 2011, with a spatial resolution of $0.5 \mathrm{~m}$ (Project 'PATRIMÔNIO CULTURAL RURAL PAULISTA: espaço privilegiado para pesquisa, educação e turismo', sponsored by FAPESP's grant no. 2007/559991). Google Street View mapping services were used to verify the inventoried spot in cases of doubt and of difficulties to identify the presence of shrubs or small trees using the satellite image. When shadows on the images prevented the visualization of the trees, researchers verified the spot using Google Street View to solve the problem (Figure 2). No overlay occurred.

Researchers correlated the surveyed data with a digital city plan provided by the city hall. In order to verify if the blocks, street flowerbeds and roundabouts were accurately positioned, the authors compared the plan drawn with images. In case of doubt about the map and the images, the team went on field surveys. After this procedure, the digital plan was corrected.

The total number of blocks found in the urban area was 11,803 , according to the digital city plan and excluding private condominiums. All individual street trees were counted, including mid-sized to large-sized trees, shrubs, palm trees, and seedlings.

The authors chose the quantitative, computerized census inventory, and the data was validated in the field using the stratified sampling technique. The term 'census' is typically used for field surveys in 


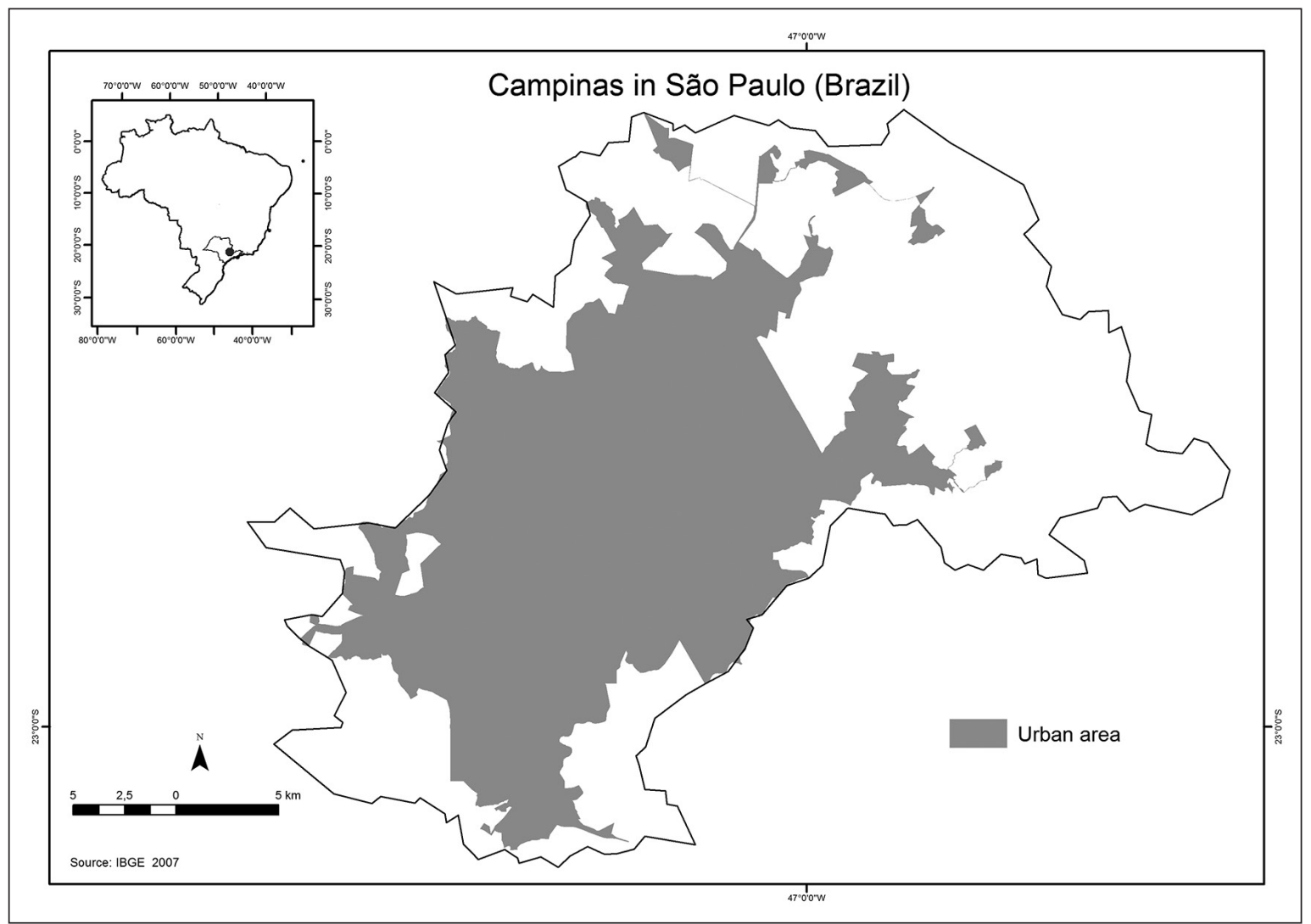

Figure 1. Location and urban area of Campinas, in São Paulo, Brazil.

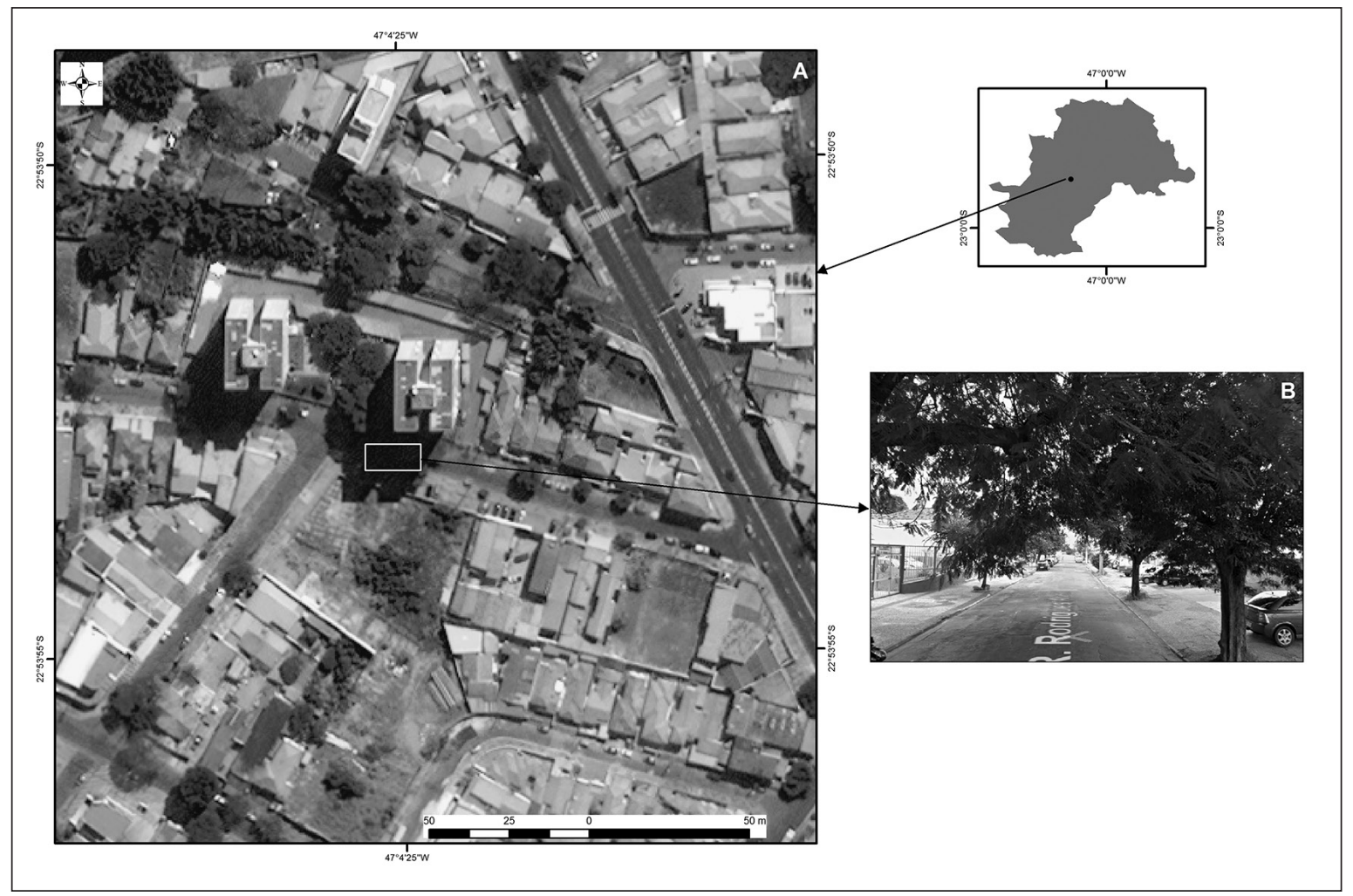

Figure 2. Shadows in WordView image (2012) and the spot verified using Google Street View. 
urban forestry, but it can also be used when referring to the total survey made using an image, as Dekker (2001) explains about census survey techniques.

A census created using image analysis requires accuracy validation in the field; sampling can be used as a way of validating image data. When it comes to street trees, the sampling may consider blocks and the number of trees per linear kilometer (Alvarez et al. 2005).

Alvarez et al. (2005) used random sampling of blocks and number of trees per linear kilometer of sidewalk, and detected significance for evaluating street trees. However, the heterogeneity of a population may lead to sampling errors when random sampling is used.

In this context, grouping peculiarities is an efficient method to improve sampling accuracy. The population may be divided into subpopulations which are homogeneous when considered individually, in a process called stratification (Cochran 2007). Couto (1994) reports that stratified sampling can be very useful for urban forestry inventories. The strata may be the neighborhood, the street density, or a set of blocks.

To obtain consistent results, the strata must have homogeneity, so that the measured values do not vary much from one unit to another. Alvarez et al. (2005), in comparative studies between random sampling and stratified sampling, showed it is necessary to establish reliable criteria for the grouping of blocks in strata based on the knowledge of the area.

The density of trees was obtained by means of the image's census and expressed as trees per linear kilometer for the perimeter of the block. The final number of trees per linear kilometer was grouped into nine classes of different densities (Figure 3), which were validated in the field by sampling. The adequate number of blocks for each class (stratum) was defined based on the sampling sufficiency test. First, 10 blocks of each class by tree density were randomly selected for the validation. Subsequently, the data collected at the field level were compared with the data obtained from the image. The error was calculated and used to estimate the total number of trees.

The assessment of the number of trees per kilometer in stratified sampling was estimated according to Cochran (2007). To obtain a coherent survey, the strata should have a homogeneity of measured values. Thus, a precise median value of any stratum estimate can be obtained using a small sample of that stratum. According to Cochran (2007), those estimates can be combined to produce an accurate estimate of the total population. The formula for this ratio is the following:

$$
\hat{R}_{e s}=\frac{\left(\sum_{h=1}^{H} \frac{x_{h}}{y_{h}} Y_{h}\right)}{Y_{t}}
$$

The components of the formula are:

$$
x_{h}=\sum_{i=1}^{n_{h}} x_{i h}, \text { and }
$$

$$
y_{h}=\sum_{i=1}^{n_{h}} x_{i h}
$$

where $x_{i n}$ is the number of trees in the $i$-th block of the $h$-th stratum, and $y_{i h}$ is the value, in linear kilometers, of sidewalk of the block in the $h$-th stratum. The total number of kilometers of sidewalk in the $h$-th stratum is:

$$
\text { [4] } \quad Y_{h}=\sum_{j=1}^{N_{h}} Y_{j h}
$$

where $N_{h}$ is the total of blocks from $h$-th stratum, and $Y_{j h}$ is the total linear kilometers of sidewalk of $j$-th block in $h$-th stratum; the total population of the linear kilometers of sidewalk variable is:

[5] $\quad Y_{T}=\sum_{h=1}^{H} Y_{h}$.

The data collected were compared to those of the 2010 census of the Brazilian Geography and Statistics Institute (IBGE 2010a). A neighborhood by neighborhood comparison was made. Once the proportions of tree individuals by number of inhabitants was obtained, the Gini coefficient was calculated, which means the 'measurement of concentration degree of a distribution whose value ranges from zero (perfect equality) to 1 (maximum inequality)' (IBGE 2007).

\section{RESULTS}

The total number of street trees found for Campinas was 120,730 individuals; all arboreal elements effectively deployed in the urban area (trees, shrubs, and palm trees) were considered. If the seedlings were include, the number rises to 127,367 . The average sampling decimal 
rep-

$\mathrm{re}$ -

sen-

t a -

tive

for

the

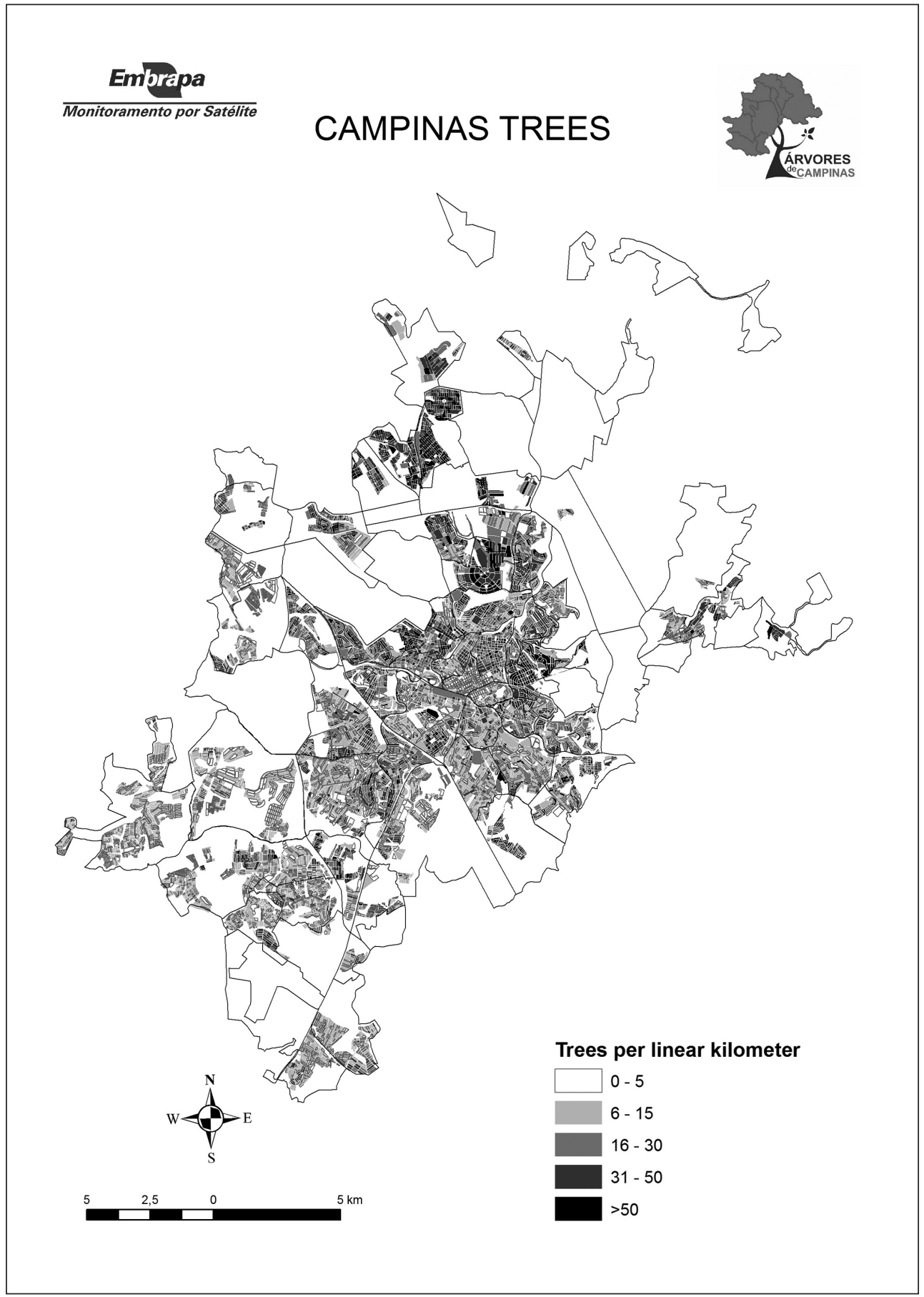

Figure 3. Tree density per linear kilometer of sidewalk in Campinas.

Table 1. Urban street trees of Campinas, São Paulo, Brazil.

\begin{tabular}{lllllllllll}
\hline & \multicolumn{1}{l}{ Stratified random sampling (density class of trees per linear kilometer) } \\
\cline { 2 - 11 } & Total & $0-5$ & $6-10$ & $11-13$ & $14-18$ & $19-23$ & $24-30$ & $31-39$ & $40-54$ & $>54$ \\
\hline Number of trees & 120,730 & 2.29 & 6.46 & 8.06 & 8.11 & 11.33 & 14.22 & 17.33 & 21.82 & 31.09 \\
Trees per linear km & & 2.25 & 13.86 & 16.77 & 16.73 & 22.17 & 27.63 & 34.61 & 44.86 & 78.21 \\
RSEy (\%) & & 34.09 & 84.09 & 45.45 & 7.68 & 9.44 & 5.92 & 3.93 & 2.20 & 2.13 \\
\hline
\end{tabular}

${ }^{\mathrm{z}}$ Includes trees, shrubs, and palms; excludes seedlings.

${ }^{y}$ RSE $=$ Relative Standard Error. 
whole area was 0.9585 . The results for each stratum are presented in Table 1, along with the data on the total urban forest and the standard error for each stratum.

The number of trees per kilometer and trees per inhabitants in the neigh- borhoods is shown in Figure 4, and the percentages of trees per kilometer and percentages of trees per inhabitants in the neighborhoods is shown in Figure 5.

In terms of qualitative classification, the downtown area had the highest propor-

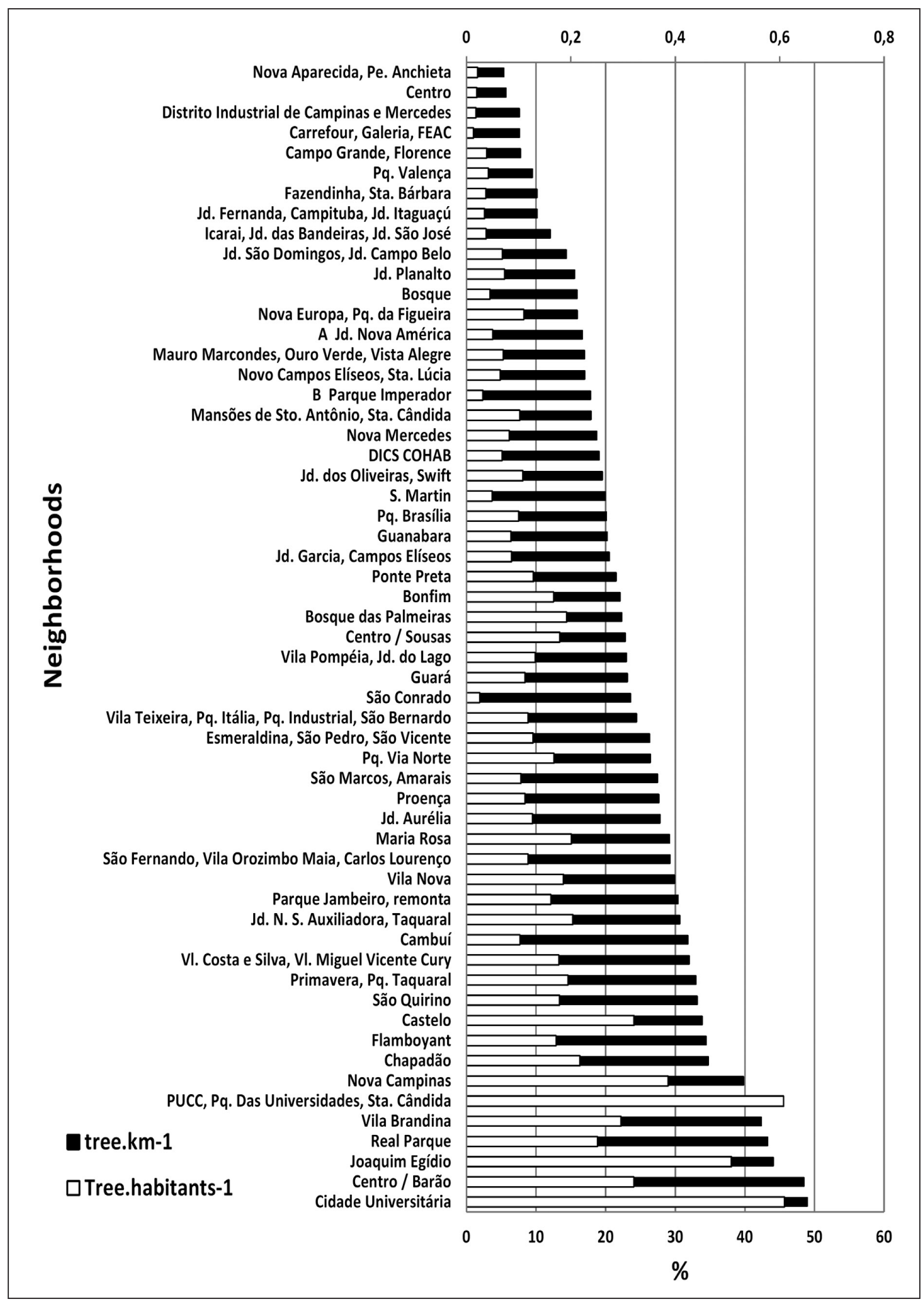

Figure 4. Number of trees per kilometer and trees per inhabitants in the neighborhoods of Campinas. 
tion of palm trees (33\%), the Real Parque neighborhood had the highest proportion of shrubs, and Joaquim Egídio had the highest proportion of trees (99\%) (Figure 6).

The process of identifying the number of trees using satellite images took three months, which is much faster than conducting a total inventory in the field, and the error was considered low, once the high-resolution images provided an accuracy error of $16 \%$ on average (Table 1).

The result of the Gini coefficient for urban forest distribution was 0.65 . The deficit of

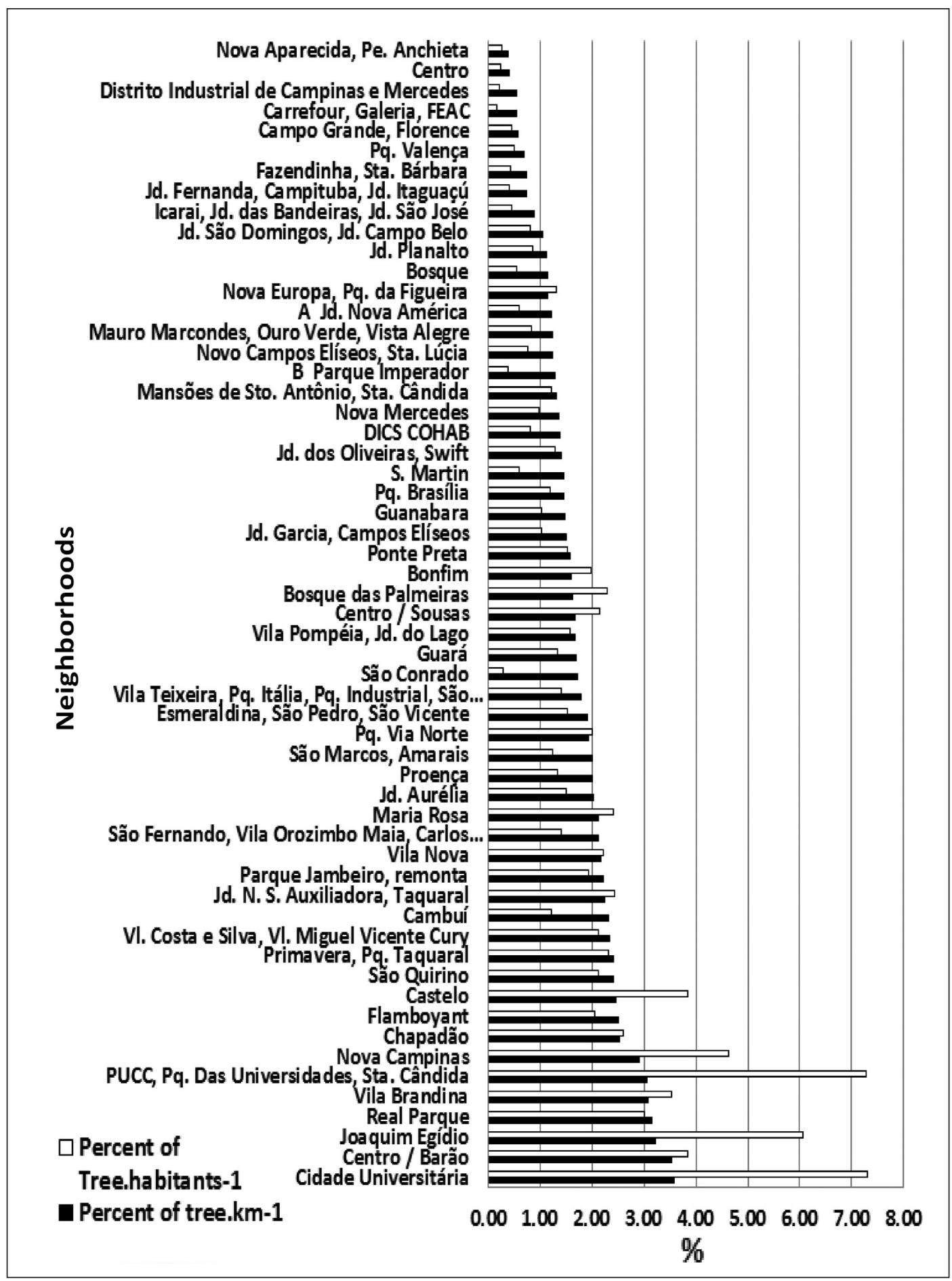

Figure 5. Percentages of trees per kilometer and percentages of trees per inhabitants in the neighborhoods of Campinas. 
street urban forest for Campinas was calculated using the presence of sidewalk trees, as foreseen in law of Campinas urban forest number 11,571/2003 (Campinas 2003): one tree at every $10 \mathrm{~m}$. The optimal number of trees on sidewalks, calculated for the urban area, was 486,318; therefore, according to these results, there is a deficit of 365,588 trees.

\section{DISCUSSION}

The method used was faster than a field census. Together, the image census and the field validation took 90 hours, whereas a census made exclusively at the field level would have taken 1,500 hours, both using a team of four people. The data obtained were accurate enough (Table 1) to estimate the real number of trees.

Qualified management of street trees, especially those on sidewalks, splitter islands, and roundabouts, depends on the analysis of the spacing for trees and the number of inhabitants of each neighborhood (Figure 5). As urban densification increases, commerce expands, and the car fleet increases. As a result, buildings advance towards the sidewalks, which are lowered, and the streets expand, thus reducing the space necessary for the trees. This is the case of the downtown area, with sparse street trees, and featuring the small amount of six trees per kilometer (Figure 4).

Historically, the City of Campinas has had an excellent history of urban forestry with abundant species diversity and medium- or largesized individual trees providing better ecological benefits. However, today the city is not different from any other metropolis. With urban sprawl, greenspaces diminish, including street trees. The rapid deployment of condominiums and building lots that do not faithfully obey the laws of land use and occupation result in the reduction of greenspaces. Santin (1999) pointed out that the government has not been taking the proper care on the approval of new condos, thus undermining the distribution of vegetation.

On the other hand, Campinas is renowned for the presence of a forest reserve within the urban area, the Santa Genebra Forest, as well as of some other native fragments within and near the urban area. These elements are essen- tial to the city's microclimate, but they depend on the city's surroundings for the maintenance of the biodiversity and for a decrease in the border effect. In this case, the street trees can be used as a way to deploy ecological corridors and connect those fragments among themselves, allowing the gene flow of species.

Studies on the street tree urban forest have aimed to diagnose the trees at the field level (Jim 2008; Nowak et al. 2008), in order to compose a future qualitative inventory. The cost of these initiatives to city halls has been high. In Brazil, few cities have managed to complete this work, and/or when they completed it, the data were already outdated due to the dynamics of urban vegetation.

The data presented here are ready to be used for management purposes (Figure 6). It is possible to segment the planning deficit by location, for example, if there is a neighborhood association mobilized for tree planting.

When compared to other works that performed field surveys, the sampling error here was smaller. Alvarez et al. (2005) found the following errors when estimating the total tree population, both for the random and the stratified sampling, when compared to the census: 17.32 and 37.05, respectively. Nowak et al. (2008) estimated the number of trees in 14 North American cities and found relative error rates from $8.1 \%$ for Atlanta, Georgia, U.S., up to $19.2 \%$ for Baltimore, Maryland; in both cases, stratified random sampling was used.

The tree distribution in the urban area of Campinas is very uneven as a whole. The total number of trees for the city was 24.8 trees $/ \mathrm{km}$, which is low when compared to Melbourne, Australia's 64.71 trees/km (Frank et al. 2006). These numbers are $25 \%$ lower than they should be. However, when researchers examine them neighborhood by neighborhood, some places were detected to already have important green spaces and a significant number of street trees, such as the Cidade Universitária neighborhood (49 trees $/ \mathrm{km}$ ). However, in other locations, such as Campo Grande/Jardim Florence, there is a complete lack of greenspaces, and there are many blocks without a single tree, with an average of 8 trees $/ \mathrm{km}$, which is only $8 \%$ of the ideal amount. 


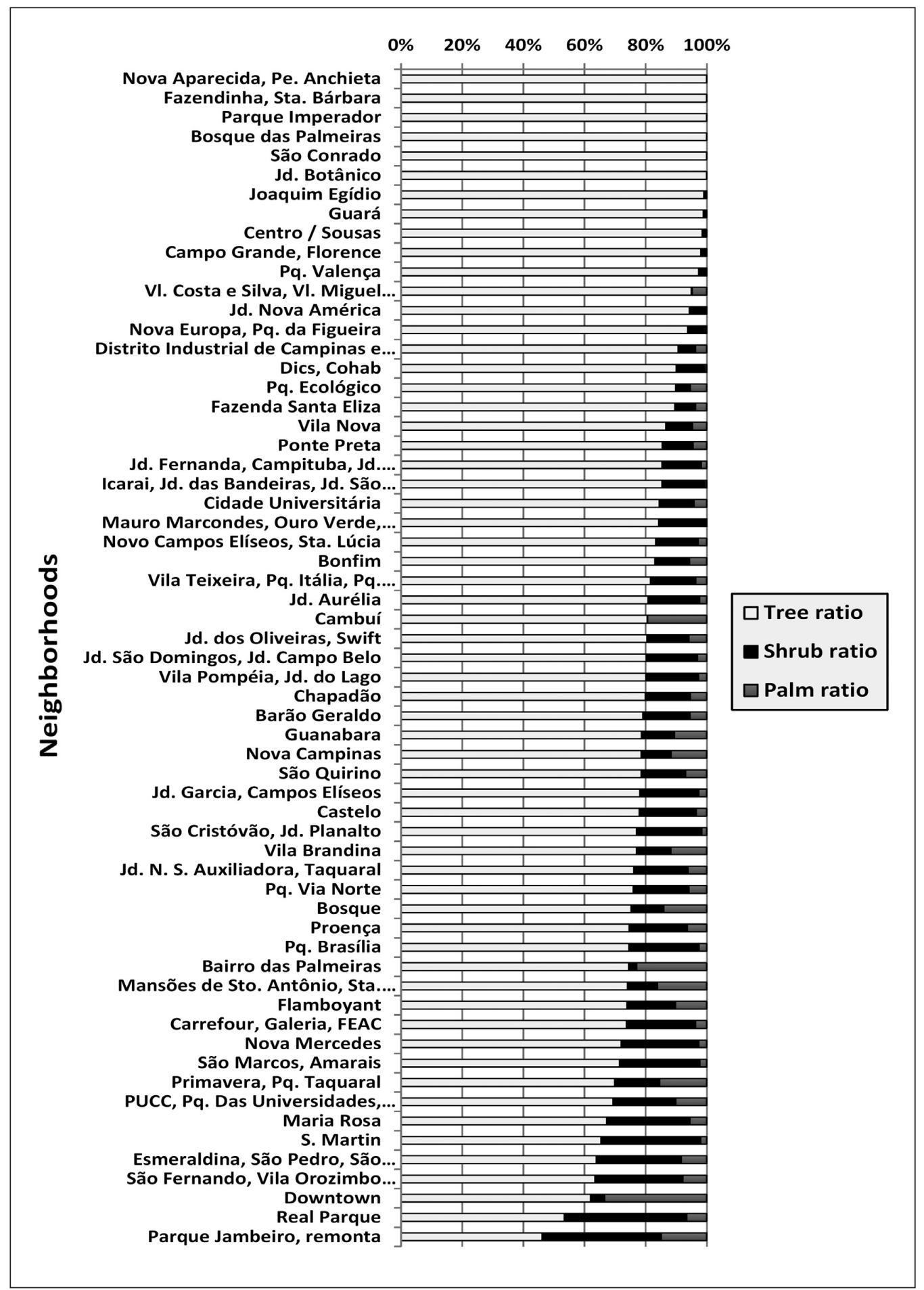

Figure 6. Ratio of trees, shrubs, and palms in the neighborhoods and in the total urban area.

The importance of tree qualification is related to the type of shading the species produces (Maco and McPherson 2002), particularly in the case of street trees (McPherson and Muchnick 2005). It is a fact that a tree provides better shading than a palm or a shrub. For example, the downtown area, which has the highest percentage of palm trees, could benefit from a plan aimed at decreasing this ratio and increasing the proportion of fuller-canopy trees.

Furthermore, the tree density per inhabitant rate is essential for deficit analyses and for 
planning planting actions. However, if evaluated in terms of population density (Figure 5), the differences in urban forestry become stronger. For example, in terms of space, there is less urban forestry in the region of Nova Aparecida/ Padre Anchieta, but when it comes to trees per inhabitant, the deficit is much stronger at the Carrefour/Galeria/FEAC neighborhood, which then moves from the fourth position to the first. When one compares Campinas with the City of Melbourne (Frank et al. 2006), there is a stronger contrast in terms of tree distribution and number of inhabitants per tree. Frank et al. (2006) found a two inhabitants per tree rate, while Campinas has nine inhabitants per tree; there is also a greater uniformity distribution in Melbourne than in Campinas.

Comparing the Gini coefficients for greenness (0.65) and income (0.58) (IBGE 2010b), researchers noted that Campinas shows greater difference between the people who live in neighborhoods with lowest and highest number of street trees than economic (income) differences between the poorest and the richest people. In fact, this number is important to enforce that priorities be given to environmental issues when it comes to improving the quality of life in the city.

These priorities are based on the number of trees to be planted at each place; however, what is the final number to be reached? Campinas has a modern law (Campinas 2003), which is technically compatible with the precepts of urban forestry, and is therefore ahead of several other Brazilian municipalities (Brun 2008). However, this does not mean that the law has been implemented and followed.

It is worth mentioning that this survey targeted trees located in public places and managed by the city for two main reasons. First, the need for planning planting actions involves neighborhoods where there have been no planting intervention or where the trees have been cut down. In Campinas, private condominiums perform their own planning and planting actions based on the city's law, and therefore these trees were not included in the survey. Second, there are no images of private lands available in the Google Street View mapping service.
This study gathered information that may be used as basis for further studies, such as: 1) a qualitative inventory of the quantified street trees; 2) a study correlating this data with the inhabitants' perceptions about the urban trees of their neighborhoods; 3) a new inventory including street trees in private plots (condominiums).

\section{CONCLUSIONS}

1. This study showed that there is great variation in the density of street trees among the neighborhoods of Campinas, in São Paulo, Brazil.

2. There are low rates of urban forest in the downtown area due to the population concentration, and in the most peripheral areas, due to the lack of planning in these developments.

3. The distribution of the street trees in the City of Campinas seems to be worse compared to the one of its inhabitants' income.

4. Public policies are necessary for the reorganization of public spaces, aimed at an urban settings with better environmental quality.

5. Urban forestry management requires a new setting of local priorities for planting actions, which may be based on the results obtained here.

Acknowledgments. To Hilton Thadeu Zarate do Couto, Ph.D., for important suggestions about forestry statistics. 


\section{LITERATURE CITED}

Alvarez, I.A. 2004. Qualidade do espaço verde urbano: Uma proposta de índice de avaliação. Piracicaba. Ph.D. Thesis, Escola Superior de Agricultura "Luiz de Queiroz"/Universidade de São Paulo, Piracicaba, Brasil.

Alvarez, I.A., D.F. Silva Filho, H.T.Z. Couto, and J.L. Polizel. 2010. Comparação entre videografia e fotografia aérea para diagnóstico da vegetação do ambiente urbano de Piracicaba, SP. Revista Árvore 34(4):691-698.

Alvarez, I.A., G.D. Velasco, H.S. Barbin, A.M.L.P. Lima, and H.T.Z Couto. 2005. Comparison of two sampling methods for estimating urban tree density. Journal of Arboriculture 31(5):209-214.

Aguirre, J.H. 2008. Arborização viária como patrimônio municipal de Campinas/SP: histórico, situação atual e potencialidades no Bairro Cambuí. MsC Thesis, Escola Superior de Agricultura "Luiz de Queiroz"/Universidade de São Paulo, Piracicaba, São Paulo Brasil.

Baeninger, R. 2005. São Paulo e suas migrações no final do século XX, Revista São Paulo em Perspectiva 19(3):84-96.

Brun, F.G.K., R.H. Fuchs, E.J.Brun, and L.E.B de Araújo. 2008. Legislação municipal do Rio Grande do Sul sobre arborização urbana: Estudo de caso, Revista da SBAU 3(3):44-64.

Campinas. 2003. Lei de Arborização Urbana No 11.571, de 17 de junho de 2003. Diário Oficial, Campinas.

Cielo Filho, R., D. Santin. 2002. Estudo florístico e fitossociológico de um fragmento florestal urbano-Bosque dos Alemães, Campinas, SP. Brazilian Journal of Botany 25(3):291-301.

Cochran, W.G. 2007. Sampling techniques, third edition. John Wiley and Sons, New York, U.S. 428 pp.

Couto, H.T.Z. 1994. Métodos de amostragem para avaliação de árvores de ruas. Congresso Brasileiro de Arborização Urbana, 2.; Encontro Nacional sobre Arborização Urbana. 5., São Luís. Proceedings... São Luís: Sociedade Brasileira de Arborização Urbana. 169-179.

Dekker, A. 2001. Adapting new technologies to census operations. Proceedings of the Symposium on Global Review of 2000 Round of Population and Housing Censuses: Mid-Decade Assessment and Future Prospects. New York, U.S.

Frank, S., G. Waters, R. Beer, and P. May. 2006. An analysis if the street tree population of greater Melbourne at the beginning of the 21st century. Arboriculture \& Urban Forestry 32(4):155-162.

Gomes, J.A.M.A., M.R.B. Torres, and L.C. Bernacci. 2005. Dinâmica da vegetação nativa de um fragmento urbano (Bosque dos Jequitibás. Campinas-SP). Report. Instituto Agronômico de Campinas. Núcleo de Pesquisa e Desenvolvimento do Jardim Botânico. Campinas, Brasil.

Gong, C.F., J. Chen, and S. Yu. 2011. Spatiotemporal dynamics of urban forest conversion through model urbanization in Shenzhen, China. International Journal of Remote Sensing 32(24):9071-9092.

Gong, C.F., J. Chen, and S. Yu. 2013. Biotic homogenization and differentiation of the flora in artificial and near-natural habitats across urban green spaces. Landscape and Urban Planning 120:58-169.
IBGE (Brazilian Institute of Geography and Statistic). 2007. Indicadores sociais mínimos. Accessed 05 July 2014. <www.ibge.gov. br/home/estatistica/populacao/condicaodevida/indicadoresminimos/conceitos.shtm>

IBGE (Brazilian Institute of Geography and Statistic). 2010a. Accessed 05 July 2014. <www.censo2010.ibge.gov.br/sinopseporsetores>

IBGE (Brazilian Institute of Geography and Statistic). $2010 \mathrm{~b}$. Accessed 05 July 2014. <http://tabnet.datasus.gov.br/cgi/ibge/ censo/cnv/ginisp.def>

Jim, C.Y. 2008. Multipurpose census methodology to assess urban forest structure in Hong Kong. Arboriculture \& Urban Forestry 34(6):366-378.

Maco, E., and G.M. McPherson. 2002. Canopy cover in street tree populations. Journal of Arboriculture 28(6):270-276.

McPherson E.G., and J. Muchnick. 2005. Effects of street tree shade on asphalt concrete pavement performance. Journal of Arboriculture 31:303-310.

Nowak, D.J., J.T. Walton, J.C. Stevens, D.E. Crane, and R.E. Hoehn. 2008. Effect of plot and sample size on timing and precision of urban forest assessments. Arboriculture \& Urban Forestry 34(6):386-390.

Santin, D.A. 1999. A vegetação remanescente do município de Campinas (SP): Mapeamento, caracterização fisionômica e florística, visando a conservação. Ph.D. Thesis, University of Campinas (UNICAMP), Campinas, Brasil.

Wood, J.P. 1999. Tree inventories and GIS in urban forestry, project report submitted to the Faculty of the Virginia Polytechnic Institute and State University in partial fulfillment of the requirements for the degree of Master in Forestry, Blacksburg, Virginia, U.S.

Ivan André Alvarez (corresponding author)

Embrapa Satellite Monitoring

Campinas-SP, Brazil

ivan.alvarez@embrapa.br

Bruna Cristina Gallo

College of Agriculture Luiz de Queiroz

University of São Paulo

Piracicaba-SP, Brazi.

Edlene Aparecida Garçon

Embrapa Satellite Monitoring

Campinas-SP, Brazil

Osvaldo Tadatomo Oshiro

Embrapa Satellite Monitoring

Campinas-SP, Brazil 
Résumé. La région métropolitaine de Campinas est la troisième ville la plus riche du Brésil. Cette étude évalue les arbres en alignement de rue de Campinas en se basant sur des données provenant d'un relevé réalisé à partir d'images satellites collectées en 2011. Tous les arbres du domaine public bordant le réseau routier ont été compilés et répartis selon les catégories suivantes : arbres, arbustes, palmiers ou jeunes plants. La densité d'arbres a été établie sur la base des images recueillies et exprimée en nombre d'arbres par kilomètre linéaire dans le périmètre retenu. Le nombre d'arbres par kilomètre linéaire a été caractérisé selon neuf classes de densité aux fins de la validation des données. Le nombre définitif d'arbres a été confirmé suite aux résultats de la validation. Le coefficient de Gini atteste que le nombre d'arbres par personne est très variable en fonction des quartiers de la ville (alors que Campinas montre une distribution plus équitable des revenus que sa répartition d'arbres de rue). Il ya une plus faible densité d'arbres dans le centre-ville en raison de la forte concentration de population, ainsi que dans les quartiers plus périphériques (banlieues), du fait de l'absence de planification urbaine lors du développement. Les résultats obtenus ici peuvent être utilisés afin de soutenir un réalignement des priorités locales en faveur de programmes de plantation visant une gestion améliorée de la foresterie urbaine.

Zusammenfassung. Die Region um die Metropole Campinas ist die drittreichste Stadt in Brasilien. Diese Studie untersucht anhand eines Katasters welches auf Auswertungen von Satellitenbildern aus 2011 basiert, die Straßenbäume in Campinas. Alle öffentlichen Bäume in dem Straßensystem wurden gezählt und unterteilt in Bäume, Sträucher, Palmen und Sämlinge. Die Dichte der Bäume erhielt man durch einen Bildzensus und wurde ausgedrückt in Baum pro linearen Kilometer für den Perimeter des Blocks. Die Anzahl der Bäume pro linearen Kilometer wurde für die Datenbewertung in neun Klassen mit unterschiedlicher Dichte eingeteilt. Die finale Anzahl der Bäume wurde anhand der Ergebnisse der Datenbewertung geschätzt. Der Gini-Faktor zeigt, dass die Anzahl der Bäume pro Einwohner in den einzelnen Stadtteilen sehr unregelmäßig ist (so hat Campinas eine gerechtere Einkommensverteilung als eine Baumverteilung). Es gibt eine niedrigere Baumdichte in der Innenstadt aufgrund der hohen Bevölkerungsdichte und in den mehr peripheren Gebieten wegen des Mangels an Gestaltungsplanung. Die hier erhaltenen Resultate können zur Unterstützung eines neuen Prioritätenkatalogs für Pflanzungen im Rahmen der urbanen Forstverwaltung verwendet werden.

Resumen. La Región Metropolitana de Campinas es la tercera ciudad más rica de Brasil. Este estudio evalúa los árboles en las calles de Campinas basado en datos de una encuesta realizada con la utilización de imágenes de satélite en el año 2011. Todos los árboles de dominio público en el sistema de calles fueron contados y separados en árboles, arbustos, palmeras y brinzales. Se obtuvo la densidad de árboles utilizando imágenes de censo expresada como árboles por kilómetro lineal para el perímetro de la manzana. El número de árboles por kilómetro lineal fue agrupado en nueve clases de diferentes densidades para la validación de datos. El número final de árboles fue estimado sobre la base de validación de los resultados. El coeficiente de Gini muestra que el número de árboles por persona es muy irregular en los barrios de la ciudad (es decir, Campinas tiene una distribución del ingreso más justa que la distribución de los árboles de la calle). Hay una menor densidad de árboles en el centro de la ciudad, debido a la alta concentración de la población, y en los barrios más periféricos, debido a la falta de diseño de planeación. Los resultados obtenidos aquí pueden ser utilizados para apoyar un nuevo establecimiento de prioridades locales para las acciones de plantación destinadas a la gestión forestal urbana. 